\title{
HAGUE CONFERENCE CONVENTIONS AND THE UNITED STATES: A EUROPEAN VIEW
}

\author{
CORNELIS D. VAN BOESCHOTEN*
}

\section{INTRODUCTION}

Apparently, the issues surrounding the Hague Conference can be approached in very different manners, as the articles by Hans Smit ${ }^{1}$ and Robert von Mehren ${ }^{2}$ in this symposium show. Although Smit has been writing since around 1961 on what he himself calls "international cooperation in litigation," his present stance reflects the idea that from the United States's point of view, the existing treaties of the Hague Conference do not improve such cooperation; one should rely, instead, upon improving domestic procedures, with U.S. procedures presenting "the best possible model for emulation by foreign countries." ${ }^{3}$ This position is, in essence, fairly isolationist, as one cannot reasonably expect other countries, even if they share the common law roots of U.S. law, to adopt U.S. procedures. Nor can one expect other countries to abandon what they consider to be the benefits of a system of conventions on civil procedure and related matters, created by the Hague Conference or another treatymaking body, such as the European Union ("EU") or the Council of Europe.

Bob von Mehren's approach, on the other hand, reflects the more internationalist approach of an experienced practitioner who does not deny the advantages that U.S. procedures may offer in certain situations, but is aware of the need for international cooperation to make U.S. procedures work. He realizes that a system of treaties may be a better instrument to achieve cooperation, as opposed to a recommendation that each state should improve its domestic procedures. ${ }^{4}$ The von Mehren approach will be more easily recognized by those who have taken part in the work of the Hague Conference

\footnotetext{
Copyright (C) 1994 by C.D. van Boeschoten

* Retired from DeBrauw, Blackstone \& Westbroek (The Hague, Netherlands); member, Netherlands delegations to sessions and special commission meetings of Hague Conference on Private International Law (1972-1989); chairman of sessions of special commissions and full conference leading to 1984 Convention on the law applicable to trusts and on their recognition (Hague Conference on Private International Law).

1. Hans Smit, International Control of International Litigation: Who Benefits?, 57 LAW \& CONTEMP. PROBS. 25 (Summer 1994).

2. Robert B. von Mehren, International Control of Civil Procedure: Who Benefits?, 57 LAW \& CONTEMP. PROBS. 13 (Summer 1994).

3. Smit, supra note 1 , at 34 .

4. See generally von Mehren, supra note 2.
} 
and have experienced the spirit of cooperation generally shared by delegations and experts seeking to work out mutually acceptable solutions, rather than only defending the superior merits of their own systems. The willingness to forgo some of the elements of one's own system of law in order to achieve international cooperation is one of the main characteristics of finding solutions through holding conventions. International cooperation cannot be achieved through the simple recommendation that countries look to other systems and change their own system of law. Why is that so?

II

\section{The Benefits of A System of TREATIES}

Systems of procedural law, like the organization of the legal profession and the traditions of the judiciary, usually have ancient roots and are very much embedded in a country's judicial system. Rules of procedure, moreover, differ greatly from one country to another; this is especially true with respect to the procedural rules of the United States, even when compared to a related system, such as the United Kingdom's. As is the case with substantive rules in the fields of family and inheritance law, harmonization of procedural laws is generally out of the question; even the EU, though not lacking in ambition, has not tried it.

Where a program of uniform laws would not be realistic, the only method of achieving certain goals is through the treatymaking process. Even in the field of procedural law, the implementation of treaties may bring about certain changes in domestic rules that one could not hope to achieve by merely recommending the amendment of internal legislation to better meet the needs of international cooperation. The EU and Lugano Conventions on jurisdiction and on enforcement of judgments in civil and commercial matters are a case in point. They show that member states are willing to (1) abandon certain cherished bases of jurisdiction, such as Article 14 of the French Civil Code ${ }^{5}$ or the forum actoris of the Netherlands Code of Civil Procedure ${ }^{6},(2)$ admit that foreign courts may validly and bindingly adjudicate upon matters involving their nationals and undertake to enforce such foreign decisions, and (3) accept bases of jurisdiction not yet recognized by their national legislations. ${ }^{7}$ Moreover, the Hague Conference, through its system of governmental central authorities communicating with each other, introduced for the first time in the 1965 Service

5. C. PR. CIV. art. 14 (Fr.).

6. RV. art. 126(3) (Neth. Code Civil Proc.); EU Convention on Jurisdiction and Enforcement in Civil and Commercial Matters, Sept. 27, 1968, art. 2, 8 I.L.M. 229 (entered into force Feb. 1, 1973) [hereinafter EU Convention].

7. EU Convention, supra note 6, art. 5, 8 I.L.M. at 232-33. 
Convention ${ }^{8}$ a mechanism which could not operate within the sole framework of noncorresponding national legislations. ${ }^{9}$

III

\section{The European PeRSPECTIVe}

From a European perspective, international cooperation in litigation does not primarily require the safeguarding of governmental interests, but the equitable balancing of the interests of plaintiffs and defendants. Certain governmental interests, such as those protected by blocking statutes, may, however, have to be taken into account. Generally, in international cases, national legislations tend to favor the plaintiff slightly; they may allow bases of jurisdiction which are not universally recognized, such as the Dutch forum actoris ${ }^{10}$ the personal service of process, the forum of Article 14 of the French Code Civil, ${ }^{11}$ the German "Gerichtstand des Vermögens,"12 and the forum arresti.

The disadvantages for the defendant may be increased if the forum allows methods of service of process which do not effectively ensure that the defendant will be notified of the proceedings in time to provide for his or her defense, or if a judgment obtained from an improper forum is nevertheless recognized and enforced outside of the forum. Thus, questions of jurisdiction, service of process, and the recognition and enforcement of judgments are interrelated. For instance, defendants residing or established in the United States would have less reason to object to the Dutch forum actoris if the EU convention on jurisdiction, while permitting this forum to subsist in relations with nonmember states, did not, in principle, allow Dutch decisions rendered against U.S. citizens or companies to be enforced in other EU member states, or, after the entry into force of the 1988 Lugano convention, ${ }^{13}$ even in a number of other European states. ${ }^{14}$ The Hague Service Convention offers a measure of protection to U.S. defendants who may not become involved in Dutch legal proceedings without proper and timely notification. The EU Convention withholds recognition from

8. Convention on the Service Abroad of Judicial and Extrajudicial Documents in Civil or Commercial Matters, opened for signature Nov. 15, 1965, art. 2, 20 U.S.T. 361, 658 U.N.T.S. 163 [hereinafter Hague Service Convention].

9. This mechanism was, afterwards, applied in the conventions on the taking of evidence, child abduction, and access to justice. Convention on the Civil Aspects of International Child Abduction, Oct. 25, 1980, S. Treaty Doc. No. 11, 99th Cong., 1st Sess., 19 I.L.M. 1501 (1983) [hereinafter Child Abduction Convention]; Convention on International Access to Justice, Oct. 25, 1980, 19 I.L.M. 1505; Convention on the Taking of Evidence Abroad in Civil or Commercial Matters, opened for signature Mar. 18, 1970, art. 2, 23 U.S.T. 2555, 847 U.N.T.S. 231 [hereinafter Hague Evidence Convention].

10. RV. art. $126(3)$ (Neth.).

11. C. Pr. Civ. art. 14 (Fr.).

12. ZPO art. 23 (F.R.G.) (jurisdiction based on the presence in the forum of any of the debtor's assets).

13. Convention on Jurisdiction and Enforcement of Judgments in Civil and Commercial Matters, Sept. 16, 1988, European Communities-European Free Trade Association, 28 I.L.M. 620 (1989).

14. Norway, Sweden, Iceland, Austria, Finland, and Switzerland. 
any decision if proper and timely notification, enabling the defendant to defend the case, has not been given. ${ }^{15}$ The EU Convention even expressly refers to the Hague Service Convention. This one example demonstrates that U.S. litigants do not need to have the United States avoid becoming a party to Hague procedural conventions or even terminate its adherence to such conventions. If the United States were to adhere to a convention like the 1971 Hague Convention on Recognition and Enforcement of Judgments ${ }^{16}$ and promote its adoption by other European states, the combined operation of the two conventions might block the enforcement of forum actoris decisions in other EU member states. The same would apply to decisions obtained from other forums not provided by the EU Convention itself.

The existence of treaties on jurisdiction and enforcement may, in the long run, promote harmonization of jurisdictional criteria. In the Netherlands, for instance, a partial revision of the Code of Civil Procedure is in progress. The revision will probably remove the Dutch forum actoris from its domestic legislation and replace it with additional forums provided for in the EU Convention but not previously recognized by the Dutch Code, such as the forum of the place of the tort or the forum solutionis. The forum arresti has already been limited to cases in which it is not possible to obtain elsewhere a decision which is recognizable and enforceable in the Netherlands. One clearly sees here the influence of the EU and Lugano Conventions, which ban the forum arresti as it is known in the U.K. and Switzerland. Again, certain U.S. objections against jurisdictionally improper forums might be overcome by the United States taking part in the system of treaties on jurisdiction, recognition, and enforcement, either on a bilateral or multilateral basis. The way in which the Lugano Convention extends the scope of the EU Convention to a number of nonmember states constitutes a clear example.

\section{IV}

\section{Procedural DifFERENCES BETWEEN NATIONS}

These observations on jurisdictional and enforcement problems draw attention to aspects that Hans Smit neglected in his article,${ }^{17}$ probably because he wanted to state the case he is making as strongly as possible. What his article lacks is the awareness that systems of procedure do indeed show very pronounced differences from one country to another, and that one cannot reasonably expect them to disappear as a result of efforts at harmonization. Many lawyers deal principally with domestic litigation and have difficulty in appreciating that rules of procedure they find logical and reasonable in their

15. EU Convention, supra note 6, art. 27, 8 I.L.M. at 236.

16. Convention on the Recognition and Enforcement of Foreign Judgments in Civil and Commercial Matters, concluded Feb. 1, 1971, Cyprus-Neth.-Port., 1972 Tractatenblad van het Koninkrijk der Nederlanden No. 144.

17. Smit, supra note 1 . 
own system of law may appear abhorrently peculiar to lawyers in other countries. Here are a few examples.

\section{A. The Taking of Evidence}

Lawyers in civil law countries like Germany, France, Belgium, and the Netherlands, generally have been taught to accept that the examination of witnesses has to be left, in principle, to an instructing judge, who draws up a summary of the testimony. Though lawyers may be-and in the Netherlands generally are-allowed to question the witness (sometimes only after the judge has concluded his interrogation), the courts find that they sometimes have to protect witnesses against unreasonable questioning by lawyers. As a matter of fact, European lawyers sometimes wish that they could question a witness in accordance with English or even U.S. standards of examination and crossexamination. It is strongly felt, however, that U.S. and, to a lesser degree, English methods of examination of witnesses, or of taking depositions, are generally far too time consuming and too costly, and do not yield significantly better results. The United States, on the other hand, tends to find court reports from the examination of witnesses by a European court to be worthless. Such different approaches cannot be easily bridged, as they stem from long-standing legal traditions. Nevertheless, oral evidence from a civil law jurisdiction sometimes has to be used in a common law jurisdiction and vice versa.

\section{B. Pretrial Discovery and Cost of Litigation}

Though some European jurisdictions provide for the preliminary hearing of witnesses or a preliminary investigation by experts, in most European jurisdictions, the examination of witnesses, the investigation by experts, or the production of further documentary evidence results from a court's decision on evidence, rendered after the exchange of a number of written statements. It is generally left to the parties to decide what documentary evidence they will make available. It is also not generally possible for parties to obtain information from the opposing party by way of interrogatories.

An institution like U.S. pretrial discovery is practically unknown in Europe. Pretrial discovery is also one of the institutions of U.S. law that may contribute to the European view that getting involved in U.S. litigation would be a major catastrophe. The pretrial discovery procedure is one of the main causes of high cost in U.S. litigation. Roughly speaking, while even a major case in the courts of the Netherlands, France, Germany, or Switzerland may still be handled by one senior member of a law firm, in certain cases assisted by an associate, a similar case in the United States may require a whole team of lawyers, and will produce a file ten or more times as large as the file of a comparable European case. For these reasons, defendants involved in U.S. litigation tend to negotiate settlements rather than litigate the case until the final judgment. So as not to rely completely on continental European objections, one can look to the view 
of another common law jurisdiction, expressed by Lord Denning, speaking for the English Court of Appeal:

As a moth is drawn to the light, so is a litigant drawn to the United States. If he can only get his case into their courts, he stands to win a fortune. At no cost to himself, and at no risk of having to pay to the other side. The lawyers there will conduct the case "on spec" as we say, or on a "contingency fee" as they say. The lawyers will charge the litigant nothing for their services but instead they will take $40 \%$ of the damages, if they win the case in court, or out of court on a settlement. If they lose, the litigant will have nothing to pay to the other side. The courts in the United States have no such cost deterrent as we have. There is also in the United States a right to trial by jury. These are prone to award fabulous damages. They are notoriously sympathetic and know that the lawyers will take their $40 \%$ before the plaintiff gets anything. All this means that the defendant can be readily forced into a settlement. The plaintiff holds all the cards. ${ }^{18}$

One may think this view is too biased and inadequate because it distinguishes insufficiently between different types of cases and different types of U.S. law firms. Nevertheless, it reflects a widespread feeling among European lawyers. Most European lawyers, having acted for European defendants in U.S. litigation, will confirm that one often prefers to settle even a strong case because it will cost less than to fight the case to a final, satisfactory conclusion. One cannot, however, reasonably expect the United States to relinquish a type of procedure to which it has grown accustomed. One has, therefore, in the field of the taking of evidence, a clear-cut case for reciprocal accommodations, which can be achieved only by way of treaty mechanisms.

\section{Jurisdiction}

Lawyers in different countries also tend to criticize each other's grounds for jurisdiction. The United States criticizes some European bases of jurisdiction, such as the forum actoris. European civil law lawyers do not appreciate jurisdiction based on personal service of process, nor the wide boundaries within which U.S. courts are prepared to accept extraterritorial jurisdiction, as in antitrust cases. One cannot usually expect other states to abandon bases of jurisdiction that form an integral part of their rules of procedure. One can, however, hope that certain conventional rules, like those of the Service and Evidence Conventions, will mitigate the disadvantages of being forced to litigate in a foreign jurisdiction and better balance the interests of plaintiffs and defendants, even if no mechanism exists to avoid conflicts of jurisdiction.

The better solution is for the United States to become a party to a convention on jurisdiction and enforcement. It is, therefore, to be welcomed that the United States has recently proposed that the Hague Conference at a minimum undertake work on a new convention dealing with the recognition and enforcement of foreign judgments. A paper, originating from Arthur von Mehren, which was submitted to a working group, sets out the possible

18. Smith Kline \& French Lab. v. Bloch, [1983] 1 W.L.R. 730, $733-34$ (C.A. 1982). 
framework of a "mixed convention."19 Such a convention would contain a "white list" states to assume jurisdiction on other grounds, but would withhold recognition and enforcement in other states of decisions obtained from such nonapproved jurisdictions. The effect of such a convention would be that the U.S., as well as European states, might continue to assume jurisdiction on grounds provided for by their national legislations but not approved by either the EU or Lugano Conventions nor by the new Hague Convention, solely to obtain decisions which are enforceable in their own forum. One wonders whether such a treaty can deal adequately with the more difficult issues of jurisdiction, but it would at least open the door to a worldwide system of recognition and enforcement, without obliging states to wholly abandon cherished grounds of jurisdiction. The difference from a traditional traité simple, only listing grounds of jurisdiction which result in enforceable decisions, would not be greatly marked; the main difference would be that states adhering to the new convention would all share the approved grounds of jurisdiction.

A new discussion aimed at a worldwide system of recognition and enforcement should be welcomed. Once such a system has come into being, it will also be easier to amend the Service and Evidence Conventions because some of the difficulties that these two conventions present are linked to the grounds upon which certain states assume jurisdiction.

\section{The Hague Child Abduction Convention}

This comment will now address some aspects of the Hague conventions in a general context, looking first at the Hague Convention on Child Abduction, ${ }^{21}$ a convention hard won by the U.S. delegation against opposition from some European members of the Hague Conference.

At the time of the Hague Convention on Child Abduction, the Dutch delegation was in a position to bridge some gaps between the different oppositions of European countries and those of, for instance, the United States and Canada. This Convention provides as its basic goal to secure the prompt return of children wrongfully removed to, or retained in, a contracting state by not permitting the courts of the state where the child is held to review the

19. "Mixed convention" refers to the von Mehren paper, which sought to combine elements of conventions like the Brussels Convention, giving directly binding grounds of jurisdiction already to be applied by the courts of the state of origin, and of the "traite simple" or indirect convention, which only provides for recognition and enforcement in a second state when the jurisdictional requirements of the convention are met but does not directly deal with jurisdiction of national courts. See also Arthur T. von Mehren's contribution to this symposium issue, Recognition and Enforcement of Foreign Judgments: A New Approach for the Hague Conference?, 57 LAw \& ConteMP. Probs. 271 (Summer 1994).

20. A "white list" is a catalogue of internationally acceptable jurisdictional standards.

21. Child Abduction Convention, supra note 9. For a general discussion of the Child Abduction Convention, see Linda Silberman's contribution to this symposium issue, Hague International Child Abduction Convention: A Progress Report, 57 LAW \& ConTEMP. ProbS. 209 (Summer 1994). 
merits of the case. ${ }^{22}$ The return may be refused only if the custodian parent has not acted expeditiously, or when there is a grave risk that the return of the child would expose the child to physical or psychological harm or otherwise place the child in an intolerable situation. Here again the implementation of the convention rules has been entrusted to central authorities.

A system has thereby been created which may contribute to the reeducation of some judicial or child welfare authorities. ${ }^{23}$ The Dutch judiciary, for instance, guided by reports from national child welfare authorities, has always had a strong tendency to examine the child's interest fully. Usually, the result of such review was a finding that a child could not be better anywhere outside the Netherlands, and in most cases, deprived parents outside of the Netherlands met with little success when seeking the return of the child, in particular, of course, when it was the mother who had wrongfully removed the child. ${ }^{24}$ Only through a convention rule, forbidding such review based on local bias, and though implementation by a governmental agency acting as central authority, can one hope to change such judicial attitudes. The Abduction Convention, therefore, has achieved something important. Countries like the United States and Canada have a clear interest in its existence and success.

\section{VI \\ The Hague Service Convention ${ }^{25}$}

It should be emphasized that the Hague Service Convention's main and primary aim is to ensure that (1) a plaintiff can validly effect service and (2) the defendant is notified properly and in time of the proceedings. The first issue raises no problems for countries like France and the Netherlands, where the formalities upon which the validity of service depends are entirely complied with in the territory of the forum, even if the defendant may be domiciled abroad. The institution of service on the office of the public prosecutor-remise au parquet-leaves it to diplomatic channels or the mechanism of the Service Convention to notify the defendant of the proceedings; service is complete and valid as soon as the document in question, such as a writ of summons, has been left at the public prosecutor's office.

The additional provisions which have to be complied with, pursuant to the Service Convention where it is applicable, only serve to ensure that the defendant is indeed informed of the proceedings. It is true that from the viewpoint of the domestic lawyer, who usually will send a copy to the defendant

22. This follows from the structure of the convention which provides for the prompt return of wrongfully removed children and leaves it to the authorities of the state of origin to decide custody issues. See id. art. 16, 19 I.L.M. at 1503.

23. "Reeducation" means that if courts are forced by a convention to return children to the country from which they were removed without using the test of the child's interest to justify keeping them where they have been wrongfully brought, such courts may lose their tendency to believe that foreign countries are detrimental to any child's welfare.

24. E.g., Judgment of May 14, 1971, HR [highest court], 1971 N.J., No. 369 (Neth.).

25. Supra note 8 . 
residing abroad, the convention only complicates matters and increases the cost of the action. ${ }^{26}$ While all provisions primarily serve the interest of the defendant, such provisions also ensure that once judgment is given, it will also be enforceable in other states.

\section{A. A Balance of Interests}

If the procedural rules of the forum make the validity of service dependent upon the formalities to be complied with abroad, the state of the forum has a clear interest in a convention. Citizens may not always need such treaty procedures because some countries, like the Netherlands, have not yet objected to service being effected by any person qualified to act pursuant to U.S. rules or to using the forms provided by U.S. law. That is not, however, the case everywhere in the world. Where a government still feels that one cannot allow service to be effected in any way other than in the manner and forms of the local law, the Service Convention, through its system of central authorities, furnishes the mechanism for service abroad where such service might otherwise be impossible. The Convention, therefore, strikes a balance between the interests of plaintiffs and those of defendants, and between the governmental interests of states having different views on sovereignty and on the protection of their own nationals.

\section{B. Volkswagenverk Aktiengesellschaft v. Schlunk}

In Volkswagenverk Aktiengesellschaft v. Schlunk, ${ }^{27}$ service was effected by serving an amended complaint on Volkswagen of America as agent for the German Volkswagenwerk. The Supreme Court held that, where an Illinois statute allowed substituted service on the U.S. subsidiary of Volkswagen, service was accomplished in the United States and the Convention did not apply. One wonders if the underlying issue in this case was really an issue of jurisdiction.

In and of itself, substituted service on a party other than the defendant accomplished within the forum is not outside the scope of the Convention; notification au parquet, service on the public prosecutor's office as known in the French and Dutch codes of civil procedure ${ }^{28}$ is a form of service accomplished within the forum. Notification au parquet is the only method whereby a defendant residing abroad can be served with process in these countries, for a complaint served directly in the state of destination would violate the rules of the forum and would not constitute a valid service of process. Nevertheless, both France and the Netherlands hold that the Convention applies and have enacted implementing legislation accordingly.

26. Certain formalities may have to be complied with in the country of destination, translations may be required, the language of a writ of summons becomes more complicated, and the court may be obliged to postpone the proceedings until it is satisfied that the documents have been properly transmitted to the defendant.

27. 486 U.S. 694 (1988).

28. C. PR. CIV. arts. 660,684 (Fr.); Rv. art. 4(8) (Neth.). 
A further case in point is the provision of the Dutch Code which allows service of writs of appeal at the office of the attorney representing the defendant in the court below. This is another example of serving process on an agent that is entirely accomplished in the territory of the forum. The Netherlands. Supreme Court has ruled that the provisions of the Service Convention have to be complied with even in this instance. ${ }^{29}$ Complying with the Service Convention in France and the Netherlands does not, however, raise any particular problems, apart from extra formalities and increased cost; jurisdiction does not depend on the method of serving process, and compliance with the Convention rules ensures that the decision will be recognized and enforced elsewhere.

It is not quite clear whether jurisdictional issues have played a role in the Volkswagen decision. If the rationale behind the chosen method was only the wish to avoid transmission of documents pursuant to Convention rules, the decision would warrant some rethinking. One must, however, admit that the language of the Convention is somewhat equivocal, for Article 1 defines its scope as covering all cases where documents have to be transmitted "for service abroad." ${ }^{30}$ From the French and Dutch perspectives, this does not exclude their methods of substitute service from the scope of the Convention, even though what happens with the transmitted documents in the state of destination is not service but, rather, notification or communication.

Since the Convention mechanism may be very useful to plaintiffs in U.S. courts, one wishes that the mandatory character of the Convention rules would be recognized. The several options they offer with respect to the methods of service give service sufficient flexibility. Some rethinking of the Convention may be appropriate after due consideration. The meetings of special commissions of the Hague Conference to discuss the operation of the Service and Evidence Conventions have already proved very useful. Renewing of conventions is, however, a slow process.

\section{VII \\ The Hague Evidence Convention}

Finally, this comment addresses the Evidence Convention. It should be known that before one of the author's clients became involved in U.S. antitrust proceedings and the author had to discuss the operation of the Convention with Bob von Mehren, the author had not been aware of the possibility that exclusivity might be claimed for the Convention. The author was unaware, therefore, that it would violate the Convention to obtain evidence located in another state by means other than applying the Convention procedures. Dutch legal practice, as a matter of fact, did consider the Convention regime as an option which might be applied if evidence located abroad could not otherwise

29. Judgment of June 27, 1986, HR [highest court], 1987 N.J., No. 764 (Neth.).

30. Hague Service Convention, supra note 8, art. 1, 20 U.S.T. at 362, 658 U.N.T.S. at $164,165$. 
be made available in Dutch proceedings. ${ }^{31}$ It is an established practice, for instance, first to determine whether witnesses residing abroad are willing to appear before the examining judge before one decides to apply for letters of request and to have the witnesses examined by a foreign court or other authority. Such a practice has not yet met with any objections from other states, but one can easily explain this by the fact that the witnesses appear on a strictly voluntary basis and cannot be compelled to appear if they are not willing. One also does not meet with any serious difficulties if lawyers involved in U.S. litigation want to have depositions from witnesses residing in the Netherlands taken by. U.S. lawyers using U.S. techniques, as long as the witnesses submit to the examination on a voluntary basis. The only point which may be in doubt is whether the evidence has been validly obtained if the lawyers have not complied with Article 17 of the Convention. ${ }^{32}$ More often than not this provision is not complied with in the Netherlands.

\section{A. The Aérospatiale Problem}

The real difficulties with the Convention begin, as Sociéte Nationale Industrielle Aérospatiale v. United States District Court for the Southern District of Iowa $a^{33}$ has shown, when a foreign court assumes jurisdiction on a basis which is not acceptable to other states and applies means of coercion that make it virtually impossible for other states not to comply. This is especially the case where the adverse party in U.S. proceedings wants to obtain information or documents from the defending party or from witnesses employed by that party. That defending party may then find himself or herself obliged to invoke privilege, relying, for instance, on a blocking statute. If the Convention procedures have not been applied, however, the party or witness concerned may not be able to invoke privilege under the laws of his or her own state as provided for by Article 11 of the Convention. ${ }^{34}$ Privilege under U.S. law may be refused on technical grounds, simply because one has not been aware of U.S. rules.

31. If a Dutch court orders the hearing of witnesses and a party wants the court to examine witnesses residing abroad, Dutch advocates generally will first try to get the witnesses to appear voluntarily before the court. There are, however, no means of coercion available to attain the appearance of a witness residing abroad. If the witness refuses to appear, one requests the court to issue letters rogatory pursuant to the Hague Evidence Convention, supra note 9, ch. I, 23 U.S.T. at 2557-64, 847 U.N.T.S. at 241-44. There is no authority in Dutch case law for the thesis that the Evidence Convention would bar the examination by the competent Dutch court of witnesses residing abroad. The Convention regime only comes into operation, therefore, in cases of unwilling witnesses or where a party is not prepared to reimburse the witness for travel expenses and loss of time.

32. This provision requires that the evidence shall be taken after obtaining the permission of a competent authority and after observing the conditions et by such authority (in the Netherlands, the President of the District Court). Hague Evidence Convention, supra note 9, art. 17, 23 U.S.T. at 2565, 847 U.N.T.S, at $235-36$.

33. 482 U.S. 522 (1987).

34. Hague Evidence Convention, supra note 9, 8 I.L.M. at 233-34. 


\title{
B. The Effects of a Mobile Society
}

David McClean, in his recent book on international judicial assistance, is probably correct when he states:

The truth of this matter seems to be that the authors of the Convention never really took into account the mobile quality of people and documents. Testimony and documentary evidence would, they envisaged, be presented either to the forum court or obtained by Letter of Request in the foreign country in which they were to be found. The Convention simply does not address the movement of persons or documents from that country to the forum State or a third State; nor, of course, the extensive nature of such movement required to comply with some American discovery orders. ${ }^{35}$

This means that the problem of exclusivity or nonexclusivity has not been fully addressed either, and that it is not reflected in any express provisions of the Convention. McClean remains critical, however, of the consequences of the U.S. stance with respect to the Evidence Convention:

\begin{abstract}
It scarcely needs to be observed that from the viewpoint of the defendant's country these arguments are unacceptable. Witnesses and documents located there are required to be taken out of that country for production before the authorities of the United States or before persons acting with the backing of the courts of that country; it must appear to be an attempt to give world-wide application to the procedural rules of the United States. There is, of course, no such difficulty if the evidence sought, though owned by a foreign corporation, is physically located within the territorial jurisdiction of the United States. ${ }^{36}$
\end{abstract}

\section{VIII}

\section{CONCLUSION}

What conclusions are to be inferred from these observations? In the first place, it can be concluded that some restraint in applying U.S. procedural rules instead of convention rules might further willingness to accommodate U.S. needs as much as possible. In the second place, even though U.S. lawyers may tend to prefer their own well-established practices, they will, nevertheless, find that they may use the Evidence Convention to a good purpose. Not all states are as liberal as the Netherlands in allowing U.S. lawyers to take evidence within their territorial jurisdictions. In particular, where one needs to obtain testimony from nonparty witnesses or documents held by third parties, the Convention will provide means of obtaining evidence that would not otherwise be available. In the spirit of cooperation, as experienced in Hague Conference sessions and in Special Commission meetings, one may eventually find ways to revise the Convention to better address the problems that have surfaced in a number of U.S. decisions.

35. David MCClean, International Judicial Assistance 111 (1992).

36. Id. at $110-11$. 